\title{
Deconstructive approach in the presentation of botanical knowledge in educational materials for students
}

\author{
Olga Fedotova ${ }^{1, *}$ and Vladimir Latun ${ }^{2}$ \\ ${ }^{1}$ Don State Technical University, 1 Gagarin sq., Rostov on Don, 344003, Russia \\ ${ }^{2}$ Southern Federal University, B. Sadovaya Str., 105/42, Rostov on Don, 344006, Russia
}

\begin{abstract}
The article discusses the latest trends in the field of presentation of natural science information for students, which have developed in the postmodern era. It is shown that botanical illustrations presented in postmodern alphabets do not reflect the morphological features of plants. When depicting plants, the author uses the technique of deconstructing images presented in ancient botanical atlases. Fragments of botanical illustrations are placed against the background of everyday scenes of the 19 th century, including those of a fantasy nature. The structural components of the botanical educational book, its content and ironic author's comments are considered. The description of plants is pseudo-academic: the texts are surreal, they combine fiction and truth, fantasy and the specifics of the action. It is concluded that the irony of the comments does not contribute to the formation of the foundations of the natural science worldview.
\end{abstract}

\section{Introduction}

Agronomy and botany are linked by a common object of study, methods and developmental history. Botanists study the patterns of structure and development, the species composition of wild plants and their groups; agronomists deal with cultivated plants [1,2]. Agronomy originated as an application of botany to crop production. Agronomists and botanists have one goal - the fullest possible use of plants for the practical needs of man, [3, 4]. The integrated use of plant resources, both natural and cultivated, is an important indicator of the general level of development of a country and its agriculture.

Botanical knowledge is an important component of the worldview picture of the world. Introduction to plant life begins in preschool childhood and continues during schooling [5]. In the history of pedagogical thought, numerous teaching aids are known that help students master the diverse world of plants [6, 7]. Botanical atlases, botany anthologies, study guides, textbooks and teaching aids, lecture courses, natural and visual herbaria, laboratory manuals are used for the presentation of natural science knowledge.

The history of an educational book on botany in Russia has its own history. Since 1809 the textbook by A.M. Teryaev "The initial foundations of botanical philosophy", which replaced the textbook by V.F. Zuev. Since 1821, the textbook by I.I. Martynov "Three

\footnotetext{
*Corresponding author: fod1953@yandex.ru
} 
Botany" introduced students with three systems of plant classification. However, the School Charter of 1828 excluded natural science from the programs of educational institutions, which marked a certain lag in Russia in the development of methods for teaching botany and creating botanical illustrations.

In general, as the researchers note, the Russian botanical illustration followed the verified path of foreign teachers and scientists, popularized and supplemented their approaches in teaching various areas of botany. In the twentieth century, teaching botany successfully combined the development of the peculiarities of the development of the plant world at the level of theory and, if possible, its practical study in natural conditions, including the examples of herbariums $[8,9,10]$.

\section{Materials and Methods}

In the 21 st century, the didactic paradigm is being revised and the tendencies of postmodernism are intensifying, which is reflected in the emergence of original concepts of creating educational products for teaching purposes $[11,12]$. New practices appear, such as deconstructive reading and writing, rhizomorphic systems of organizing the learning process, etc. [13]. The problem of this article is to answer the question - how in educational books created in the logic of postmodern pedagogy the content and methodological approach to teach traditional school academic discipline - botany?

The answer to this question can be made if an attempt is made to confirm or refute hypothetical statements that the conceptual approach to educational materials is changing in the postmodern era. An educational book loses its mode of academicity and at the same time acquires new characteristics that were not characteristic of it before - parody, paradox, irony [14].

The empirical object of research is the textbook on botany Barrenetxea, I. Bombástica Naturalis [15], published in Spain in 2010. This edition is characterized as one of the variants of the postmodern alphabet on the basis that the botanical names in Latin are presented in alphabetical order [16].

The Russian translated edition presents this educational book as a literary and artistic publication intended for students of secondary school age.

Research methods - historical and genetic method, analysis, synthesis, comparison, interpretation [17].

\section{Results}

Deconstructive writing is one of the most typical features of postmodern pedagogy. Currently, the term "deconstructive writing" refers both to the organization of students' activities and to the products of the creative or intellectual activity of subject teachers, created or used for educational purposes, as well as teaching aids. Deconstruction as a method involves breaking the integrity into its component parts and creating new compositions from them, which include components that are not necessarily represented in the original version. What is created anew should, as J. Derrida argued, read "like a text, not a document" [18]. Nevertheless, when analyzing a new text made in a deconstructive style, it is always necessary to proceed from the fact that in its most original final version, this text already had some prototype, which was deconstructed.

Currently, there are many options that make it possible to judge the application of the deconstruction method when creating a new educational product [19]. Consider the qualitative originality of the educational book on botany Barrenetxea, I. Bombástica Naturalis [15], published in Spain in 2010. 
Following the logic of deconstruction, the author chooses a prototype, which are illustrated botanical treatises published before 1810. The preserved style of the cover, as well as the clothes of the characters introduced into the narrative, made strictly according to the fashion of the beginning of the 19th century, testify to the connection with these publications.

In the structure of the textbook, some elements of the traditional scientific publication apparatus of the publication apparatus are preserved - the output data (the name of the author on whose behalf the presentation is made), the Preface about the possibility of using the educational book, the Afterword posted on the last page of the cover. As in the present botanical treatise, the names of plants are given in Latin, which allows the authenticity of the botanical classifications to be maintained. The introduction of each botanical nomination is accompanied by an illustration that reflects the postmodern discourse of content presentation, built on the idea of a deconstructive approach.

Let's consider several typical examples that characterize the author's way of accessing the deconstruction procedure. Figure 1 presents options for the presentation of information of a botanical nature.

Botanical illustrations of the early 19th

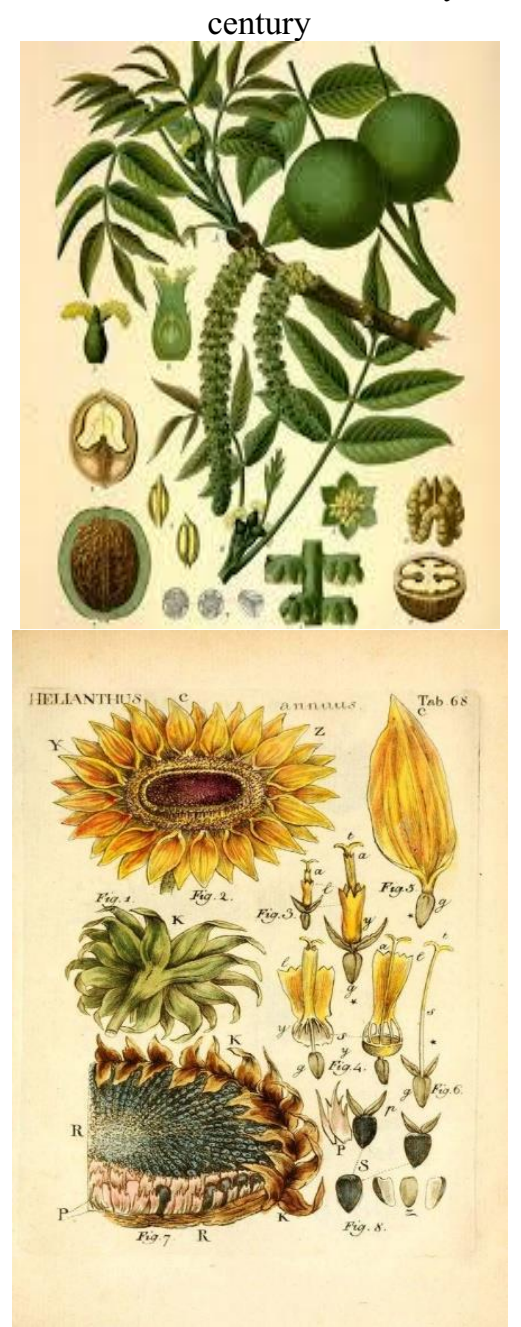

Illustrations in the study book Bombástica Naturalis

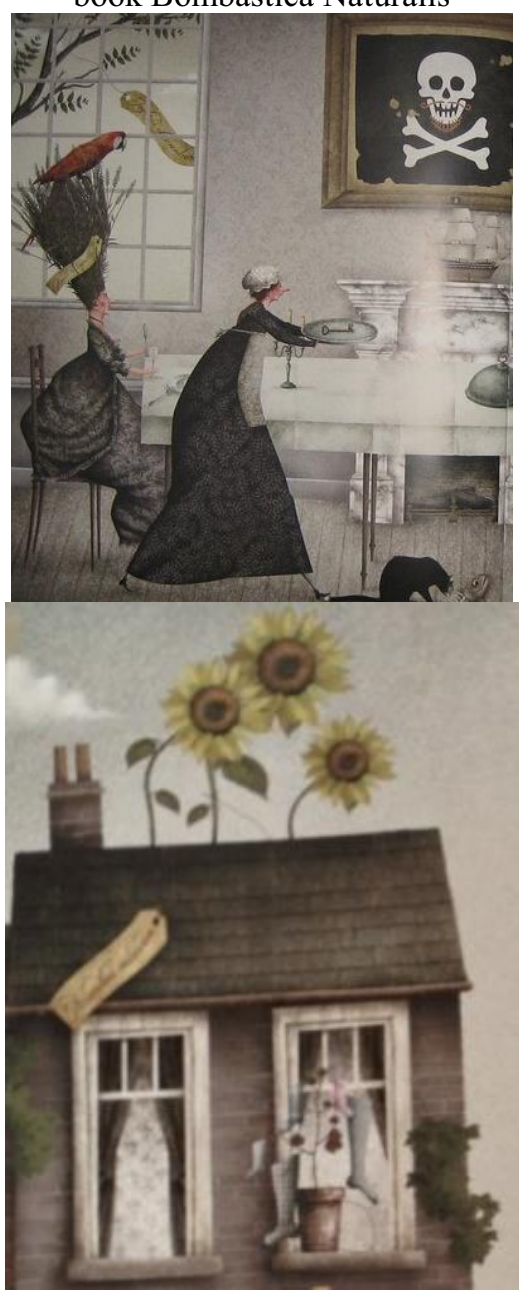



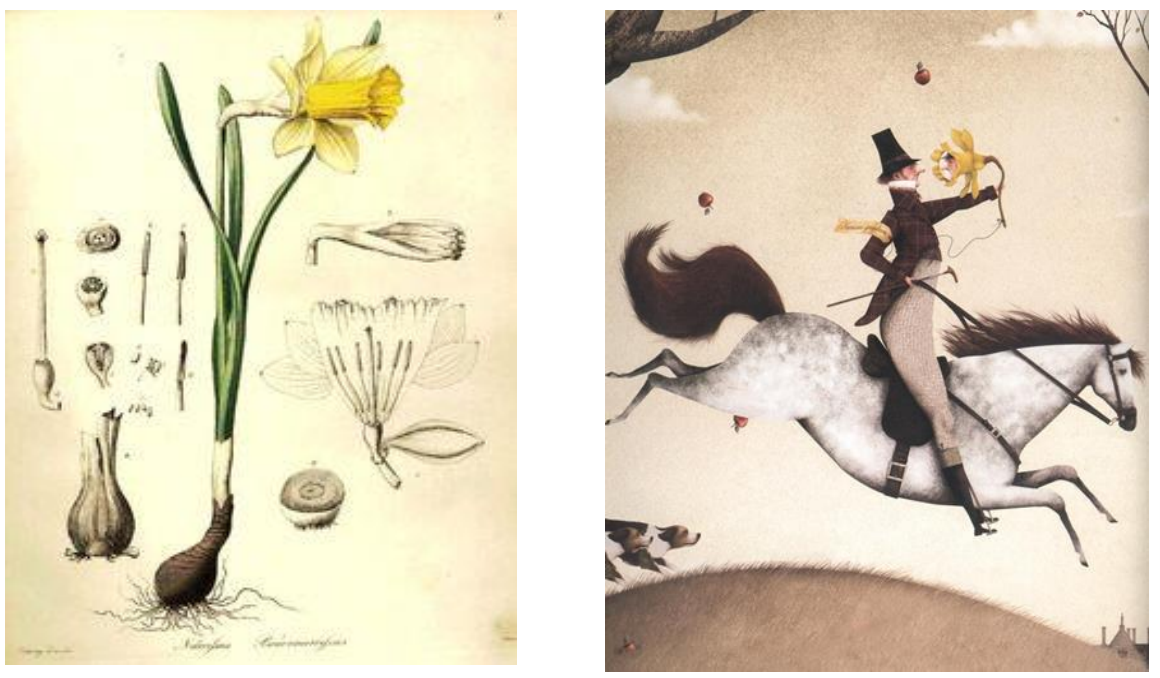

Fig. 1. Decomposition of botanical illustrations in the educational book Bombástica Naturalis [15].

The sequence of botanical illustrations in the publication is presented in alphabetical order of the Latin names of plants. Latin names can be found on the tag attached to the plant on display. In the comments, each plant described on the tag and belonging to a particular botanical class receives the author's definition, reflecting the possible fantasy function of the plant in a humorous presentation of the material (Fig. 2 Horsetail). The description of plants is pseudo-academic: the texts are surreal, they combine fiction and truth, fantasy and the specifics of the action.

Cover illustrations are made in the style of naturalistic engravings of the early 19th century. As it follows from the illustrations presented in Figure №, the drawings presented by the author as "botanical illustrations", in contrast to the botanical illustrations of the 19th century, do not reflect the elements of plant morphology [20].

The images of plants are recognizable, but do not have an academic character; they are "inserted" into a variety of everyday plots of a domestic nature. An adventurous everyday plot dominates, attracting the attention of students. He puts them into a state of tension, since the characters, dressed in expensive bourgeois clothes of the 19th century, perform ridiculous actions with plants, using them in the most awkward functions (Figure 2).

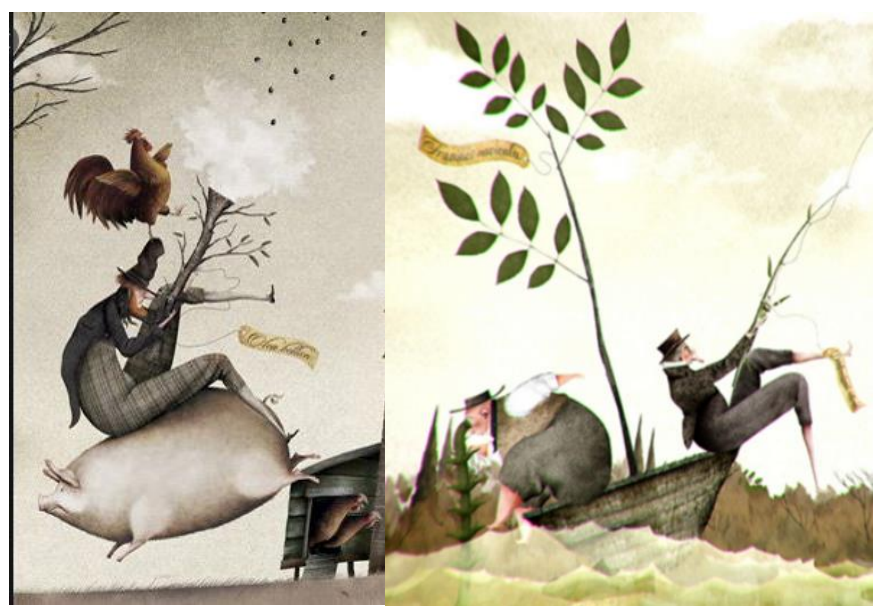

Fig. 2. Unconventional (illogical) use of plants in didactic illustrations [15]. 
Instead of the classic botanical descriptions, which are an obligatory part of the uvrages, the name of the plants is presented in the form of a new ironic-parody terminological series [21]. For example, the nut is designated as "Walnut greek casket (walnut casket)", ("Acanthus columnata [Acanto columna]" "Buxus labyrinthus [Boj laberinto]".

The walnut tree illustration shown in Fig. №, has the following explanatory inscription: "This type of walnut will finally make it possible to forever forget about the huge torture tool called "nutcracker" and received the formidable name of the Nutcracker among the people. On our walnut crown, only once does the key ripen, allowing you to open any walnut of this particular tree. Of course, it should be kept away from the envious eyes of the insidious manufacturers of the aforementioned barbaric device" [15, p. 14]. The text is a pure pun, has a fantasy-surreal character and, in fact, is nonsense.

The content of some plant descriptions is not only absurd, but also unscientific. So, the description of a sunflower contains the statement that this plant is able to accumulate the heat of the sun and give off the heat accumulated during the day at night, warming both the whole house and each room separately.In reality, the sunflower is a plant that has the property of heliotropism - changing the location of the flower in according to the trajectory of the sun.

However, it would be wrong to say that botanical illustrations are based on no references to European cultural heritage and scientific approaches and theories of other disciplines. As follows from the illustration "Narcissus", the author is familiar not only with the ancient Greek myth about the narcissistic youth Narcissus, but also with the psychological theory of morbidly pathological character accentuation, which was entrenched in the writings of Sigmund Freud under the name "narcissism."

There is an attempt to imitate the scientific nature by referring to the non-existent work of Dr. Octavius Gamelan: the title of the work («Bestiarium impossible»), the year of publication (1776) and the page number are given. At the same time, it is argued that there is a caterpillar "cottonium textilis minima", which, like a worm, spins socks.

\section{Conclusions}

Deconstructive writing as an approach to creating texts for educational purposes has an internal reference to travelism, which postulates the presence of a plurality of worlds. In the author's conception presented in the book, the natural science content does not correspond to the objective reality. There is an absurd use of plants, for example, the use of horsetail to observe the underwater world from a boat while fishing, etc.).

Grotesque characters are presented in most cases in ridiculous situations and poses that have nothing to do with reality (riding a pig, flying in a balloon from a pear fruit, etc.). Plant names (with the exception of the Latin version) are often presented in an unusual function. Stylistically, the materials presented are close to the idea of postmodern citation, which allows one to find some echoes of the scientific text in the form of classical Latin names of plants, presented in botanical atlases of the late 18th - early 19th centuries.

Thus, it can be argued that the author deconstructs the original text, removing from its content individual semantic blocks in the form of Latin names and botanical illustrations, and then creates a new version of the educational product, offering plots of the use of plants bearing the imprint of irony, cartoon, and shocking.

\section{References}

1. J. Andersson, K. Giller, Experimental agriculture, 55(2), 157-162 (2019) DOI: $10.1017 / \mathrm{S} 0014479719000024$

2. J. Sun, B.-Z. Yuan, Current science 19 (3), 438-446 DOI: 10.18520/cs/v119/i3/438-446 
3. M. Langensiepen, M. Jansen, A. Wingler, Environmental and experimental botany 178 (2020) DOI: 10.1016/j.envexpbot.2020.104125

4. J. Sun, B.-Z. Yuan, Current science 117(9), 1449-1458 (2019)

5. M. Murcia, J. Pedro, M. Ruiz-Funes, Paedagogica historica 56(12), 200-216 (2020) DOI: 10.1080/00309230.2019.1622578

6. L. Kelly, M. Lawrence, Brittonia 68(3), 356-362 (2016) DOI: 10.1007/s12228-0169427-3

7. F. Bowcutt, T. Caulkins, ISIS 111(3), 614-622 (2020) DOI: 10.1086/711071

8. E. Regan, A. Vergou, S. Kapelari, Innovations in Higher Education Teaching and Learning 1, 175-199 (2014) DOI: 10.1108/S2055-364120140000001010

9. F. Guimaraes, EDULEARN11, 4534-4540 (2011)

10. J. Mathur, Botany-Botanique 92(9), 628-628 (2014)

11. O. Fedotova, V. Latun, E3S Web of Conferences 210 (2020) DOI: https://doi.org/10.1051/e3sconf/202021018047

12. O. Fedotova, LUMEN 2013 92, 328-333 (2013) DOI: 10.1016/j.sbspro.2013.08.680

13. O. Fedotova, V. Latun, E3S Web of Conferences 210 (2020) DOI: https://doi.org/10.1051/e3sconf/202021015003

14. P. Ermakov, O. Fedotova, Procedia, social and behavioral sciences 214, 876-881 (2015)

15. I. Barrenetxea, Bombástica Naturalis (A Buen Paso, Barcelona, 2010)

16. M.S. Álvarez, Ocnos. Revista de Estudios sobre lectura 14, 42-64 (2015)

17. L. Cohen, L Manion, K. Morrison, Research Method s in Education (Routledge, NY, 2008)

18. P. Bornedal, European legacy-toward new paradigms 20(7), 699-714 (2015) DOI: $10.1080 / 10848770.2015 .1067957$

19. V. Gvozden, Primerjalna knjizevnost 43(2), 41-60 (2020) DOI: 10.3986/pkn.v43.i2.02

20. H. Hiary, H. Saadeh, M. Saadeh, IET computer vision 12(6), 855-862 (2018) DOI: 10.1049/iet-cvi.2017.0155

21. H. Lack, Regnum Vegetabile 153, 121-137 (2011) 